\title{
Conservative Media Consumers Less Likely to Wear Masks and Less Worried About COVID-19
}

\author{
Lawrence C. Hamilton and Thomas G. Safford
}

The Carsey Perspectives series presents new ways of looking at issues affecting our society and the world. Any opinions, findings, and conclusions or recommendations expressed in this material are those of the authors and do not necessarily reflect the views of the sponsors or publisher.

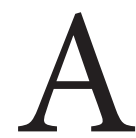

new survey of 959 New Hampshire residents, conducted by Carsey School researchers in July 2020, confirmed that most see the need for continuing precautions regarding COVID-19. ${ }^{1}$ Mask wearing and perceptions of the pandemic's seriousness vary widely, however, depending on where people get their news. Overall, more than three-quarters reported that they always wear a mask in public, or always do so unless they are outdoors and can maintain social distance. Although most reported being careful, it appears that they also recognize that other people might not be. Majorities worry that they or family members could become sick, and think that, for the country, the worst of the pandemic is yet to come. On the key policy question of whether governments should give higher priority to restarting the economy or to containing the spread of COVID-19, survey respondents chose containing the spread by a 2 to 1 margin.

In July 2020, while other developed nations brought COVID-19 infection rates down, the U.S. situation continued to worsen-surging past 4 million total cases and averaging more than 60,000 new cases and 1,000 deaths per day. The state of New Hampshire remained a relative bright spot in the United States, averaging between twenty and thirty new cases and one or two deaths per day. New Hampshire was spared the severe early impacts that hit New York and other Northeastern cities following an influx of travelers returning from Europe, and as of July it had been spared the wave breaking in Sunbelt states that had rushed to reopen. New Hampshire's comparative good fortune in the pandemic so far owed partly to an informed public response, in which residents observed health precautions. By the time Governor

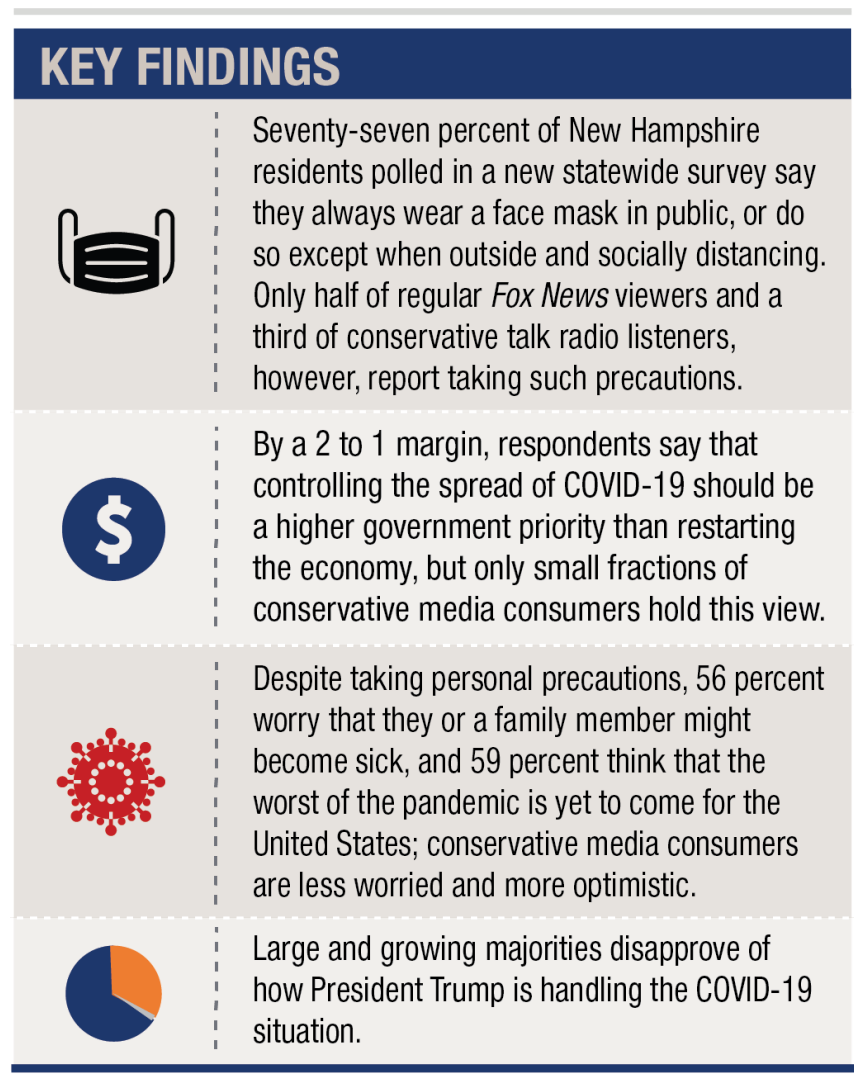

Chris Sununu issued a formal stay-at-home order on March 26, surveys showed that most people were already making major changes in their daily routines, such as leaving home less often. ${ }^{2}$ Behavioral change helped slow the spread of infections in the state early on and after a partial reopening that started in June.

\section{News Sources and Perceptions of the Pandemic}

Correlations between pandemic behavior or perceptions and news media sources are illustrated in Figure 1. (See the last section of this brief for survey question wording.) Respondents who frequently watch Fox News, where commentators have emphasized personal freedoms while downplaying scientific recommendations to wear a mask and the overall seriousness of the pandemic, reported less frequent 
mask wearing and worried less that they or family members might become sick. News media gaps were even wider on two questions about the response to and trajectory of the pandemic. Eighty-one percent of those who never watch Fox News, compared with just 12 percent of frequent viewers, said that the government's highest priority should be containing the spread of the virus instead of restarting the economy. Reflecting warnings from scientists about the fall and winter ahead, 78 percent of those who never watch Fox News thought that the worst is yet to come for the United States, compared to only 21 percent of frequent Fox News viewers. ${ }^{3}$

Figure 2 charts even wider differences involving conservative talk radio listeners. Only one-third of frequent listeners (compared with 87 percent of non-listeners) said they always wear masks in public, or do so except when outside and socially distancing-with most reporting that they only wear masks "sometimes" or never. Just 15 percent of listeners (compared with 67 percent of non-listeners) worry that they or family members might become sick. Only 3 percent of listeners (vs. 76 percent of non-listeners) agree that the government's highest priority should be containing the spread of the virus rather than restarting the economy. Six percent of listeners (vs. 75 percent of non-listeners) think that the worst is yet to come.

\section{FIGURE 1. BEHAVIOR AND PERCEPTIONS IN THE COVID-19 PANDEMIC, BY FREQUENCY OF WATCHING FOX NEWS}

(a) Wear mask in public unless outside/distancing

(b) Worried for your health or family

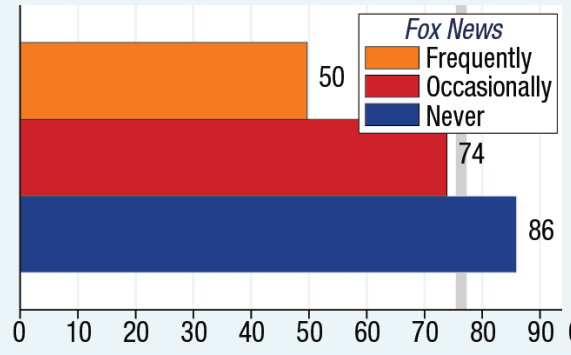

(c) Highest priority is containing the virus

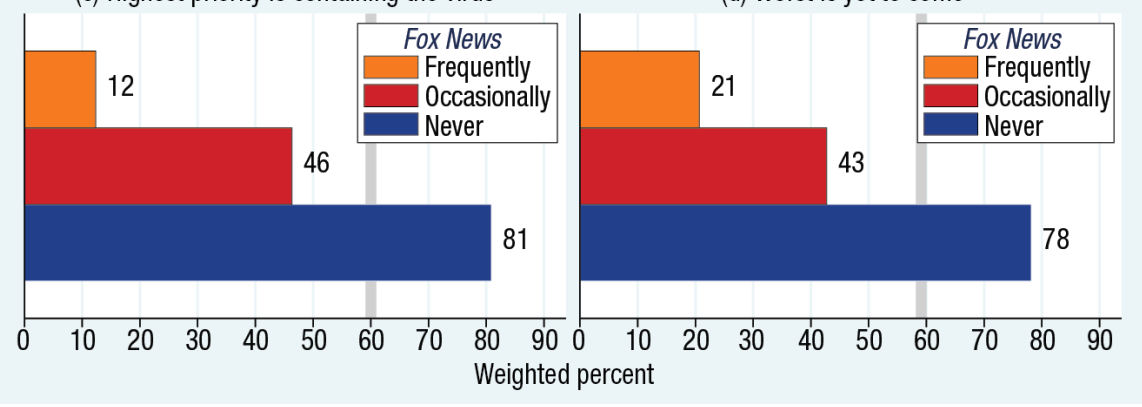

Note: Vertical gray lines mark the overall response for each question.

Source: NH Granite State Panel, July $2020(n=959)$.

\section{FIGURE 2. BEHAVIOR AND PERCEPTIONS IN THE COVID-19 PANDEMIC, BY FREQUENCY OF LISTENING TO CONSERVATIVE TALK RADIO}

(a) Wear mask in public unless outside/distancing (b) Worried for your health or family
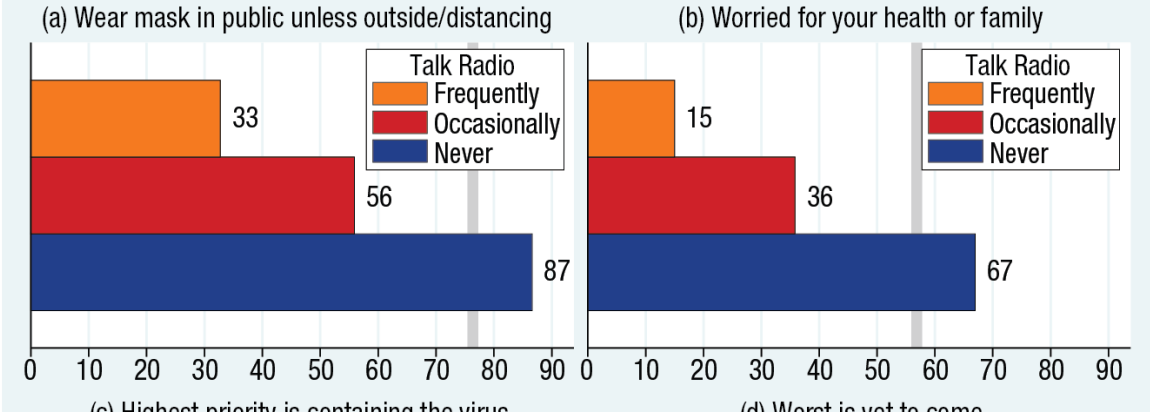

(c) Highest priority is containing the virus

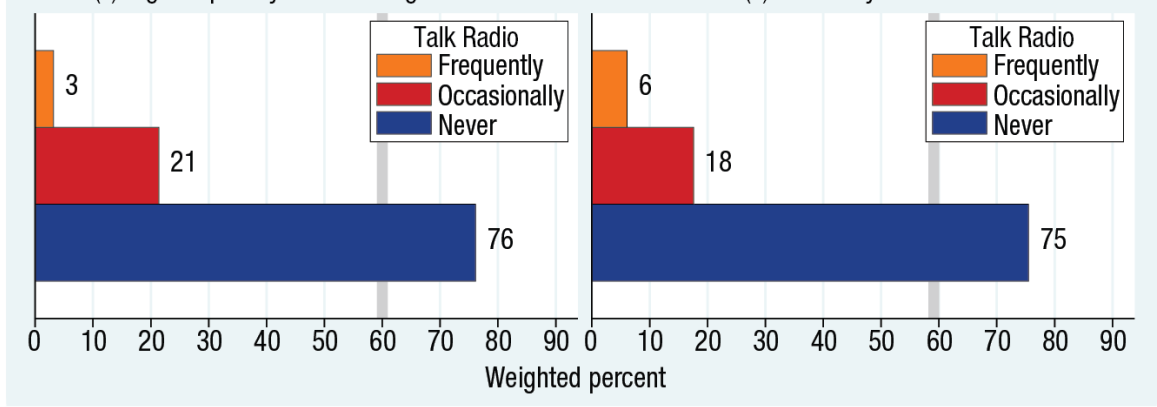

Note: Vertical gray lines mark the overall response to each question. Source: NH Granite State Panel, July 2020 ( $n=959)$. 
Figures 1 and 2 chart who is taking the pandemic most seriously. ${ }^{4}$ Conversely, we could have drawn similar figures to portray who does not take it as seriously, with mirror-image results (not shown). For example, among frequent Fox News viewers, 44 percent said they wear masks sometimes or never, and 6 percent declined to answer. Similarly, 45 percent are not at all worried that they or their family might get sick, 47 percent think that the worst is behind us, 21 percent believe that COVID-19 has not really been a problem, and 78 percent said that restarting the economy should be a higher priority than containing the spread of the virus.

Individual behavior such as mask wearing and social distancing can play a key role in slowing spread of the virus, as do government policies on reopening. The differences in behavior and opinions charted in Figures 1 and 2 thus have real consequences. Effects of media consumption on science perceptions are well known from earlier research on topics such as climate change, ${ }^{5}$ as are connections between political identity and views on public health issues including vaccines ${ }^{6}$ and the 2016 Zika virus pandemic. ${ }^{7}$ From the perspective of previous research, the general trends in Figures 1 and 2 are not surprising, although the size of these medialinked divisions in the midst of a global pandemic may be.

\section{Approval of President Trump's Response}

From the outset of the pandemic, President Trump downplayed its seriousness, and his statements doing so were amplified by conservative media outlets. ${ }^{8}$ This messaging may explain why Fox News viewers and talk radio listeners less often wear masks or worry about health risks, while feeling that the economy should reopen now and that the pandemic is fading or was not a real problem. Directly addressing Trump's role in the crisis, the July survey repeated a question we had asked earlier in March.

Generally speaking, do you approve or disapprove of the way President Trump is handling the coronavirus (COVID-19) situation?

\section{FIGURE 3. DO YOU APPROVE OR DISAPPROVE OF THE WAY PRESIDENT} TRUMP IS HANDLING THE COVID-19 SITUATION? (MARCH AND JULY 2020)

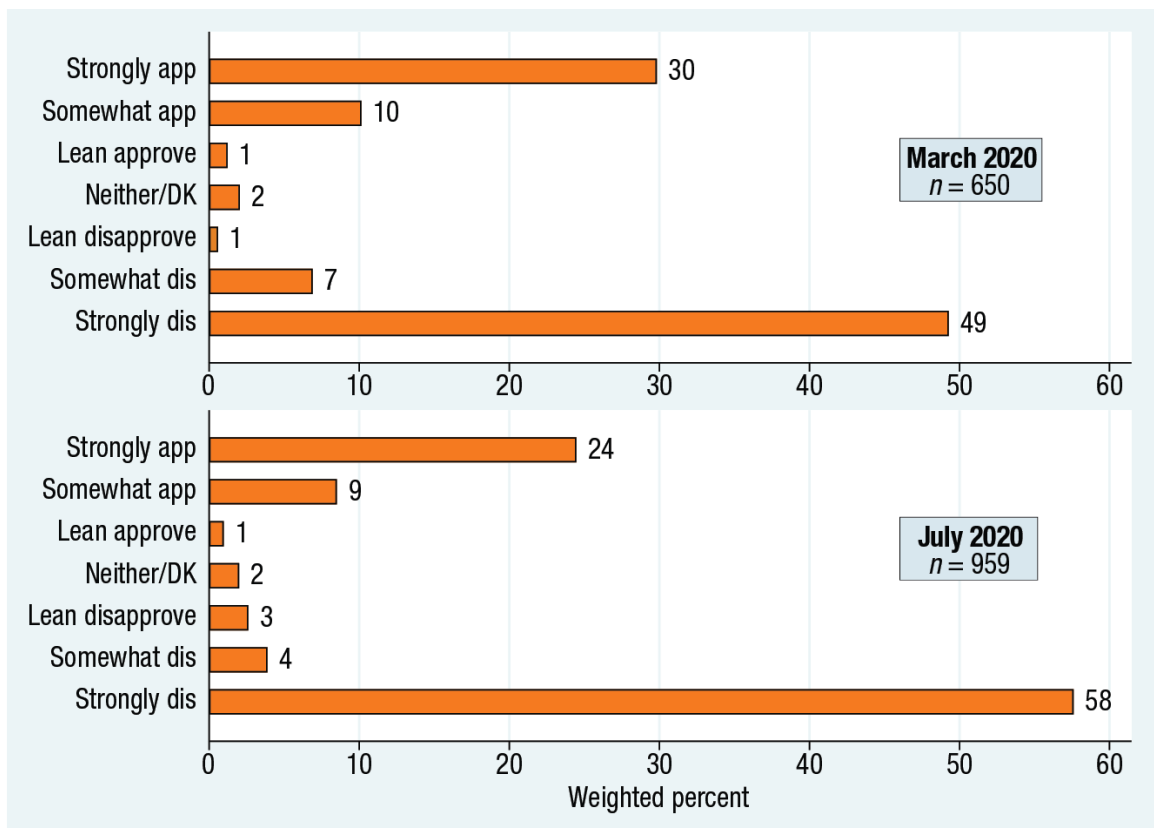

Source: NH Granite State Panel, March and July $2020(n=1,609)$.
Figure 3 compares March and July survey results. In March, 49 percent strongly disapproved of how Trump was handling the crisis, and only 30 percent strongly approved (a gap of 19 points). By July, as the United States was experiencing around 65,000 new infections and 1,000 COVID-19 deaths every day, accompanied by high unemployment and continuing recession, views of the administration had grown even more negative. Strong disapproval outweighed strong approval by 58 to 24 percent (a 34-point gap). In-between views were uncommon on both surveys, and only 2 percent expressed no opinion. 
Figure 4 breaks down Trump's July approval ratings by party. Democrats and independents overwhelmingly disapprove: 98 percent strong disapproval among Democrats, and 63 percent among independents. A majority of Republicans, on the other hand, strongly approve (56 percent). Strikingly, however, even among Republicans 25 percent either disapproved or otherwise did not express approval.

\section{COVID-19 Questions and Results}

Figures 1 and 2 summarized results on four COVID-19 questions from the July survey. This section goes into more detail on question wording and responses. The first two questions asked about personal behavior and concerns.

What best describes your own current use of a face mask (covering mouth and nose) as a COVID-19 precaution, when going out in public places such as stores, restaurants, or parks?

- I always use a face mask in public places.

- I always use a face mask when out in public, unless I am outdoors and can maintain social distance.

- I sometimes use a face mask in public places.

- I never use a face mask in public places.

Figure 5 charts mask-wearing responses. In keeping with contemporary scientific advice, more than three-quarters of the respondents said that they always wear a mask in public or always do so except when outdoors and social distancing.

\section{FIGURE 4. APPROVAL OR DISAPPROVAL OF TRUMP'S HANDLING OF COVID-19, BY POLITICAL PARTY}

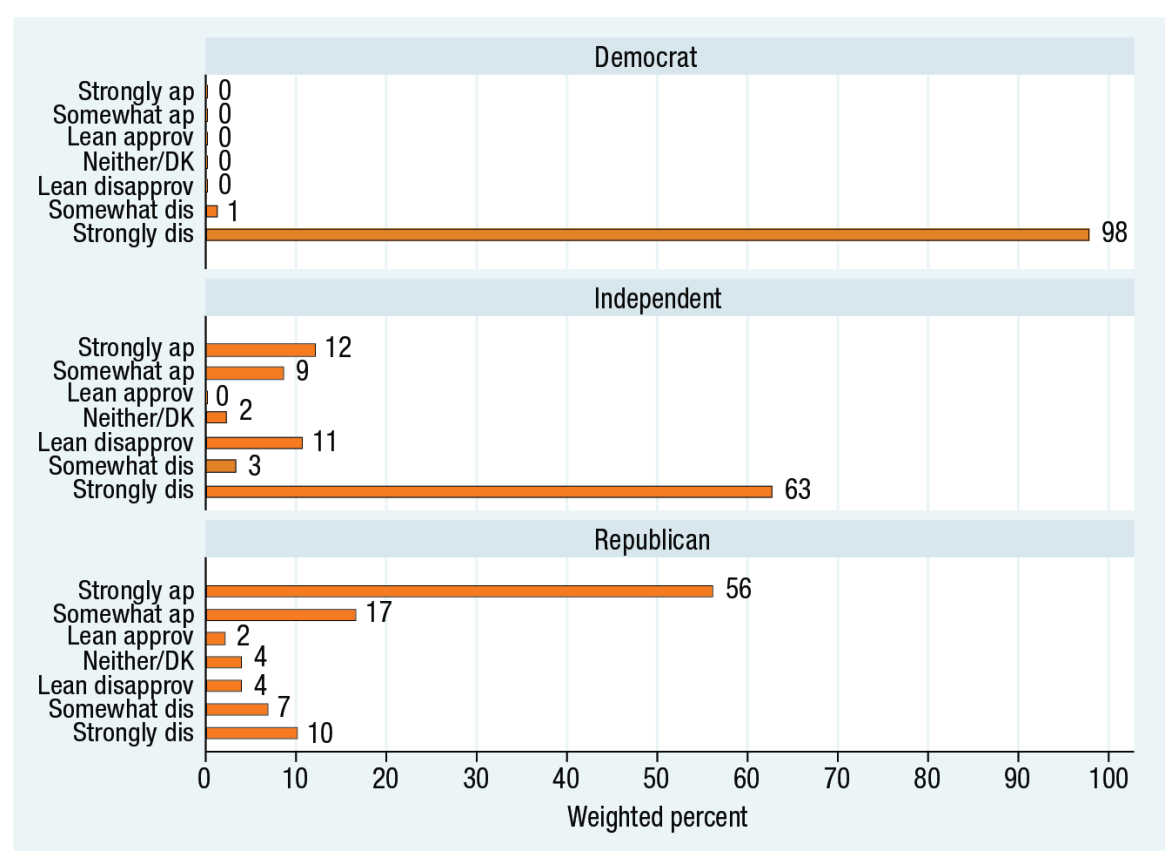

Source: NH Granite State Panel, July 2020 ( $n=959)$.

\section{FIGURE 5. WHICH BEST DESCRIBES YOUR OWN CURRENT USE OF A FACE MASK?}

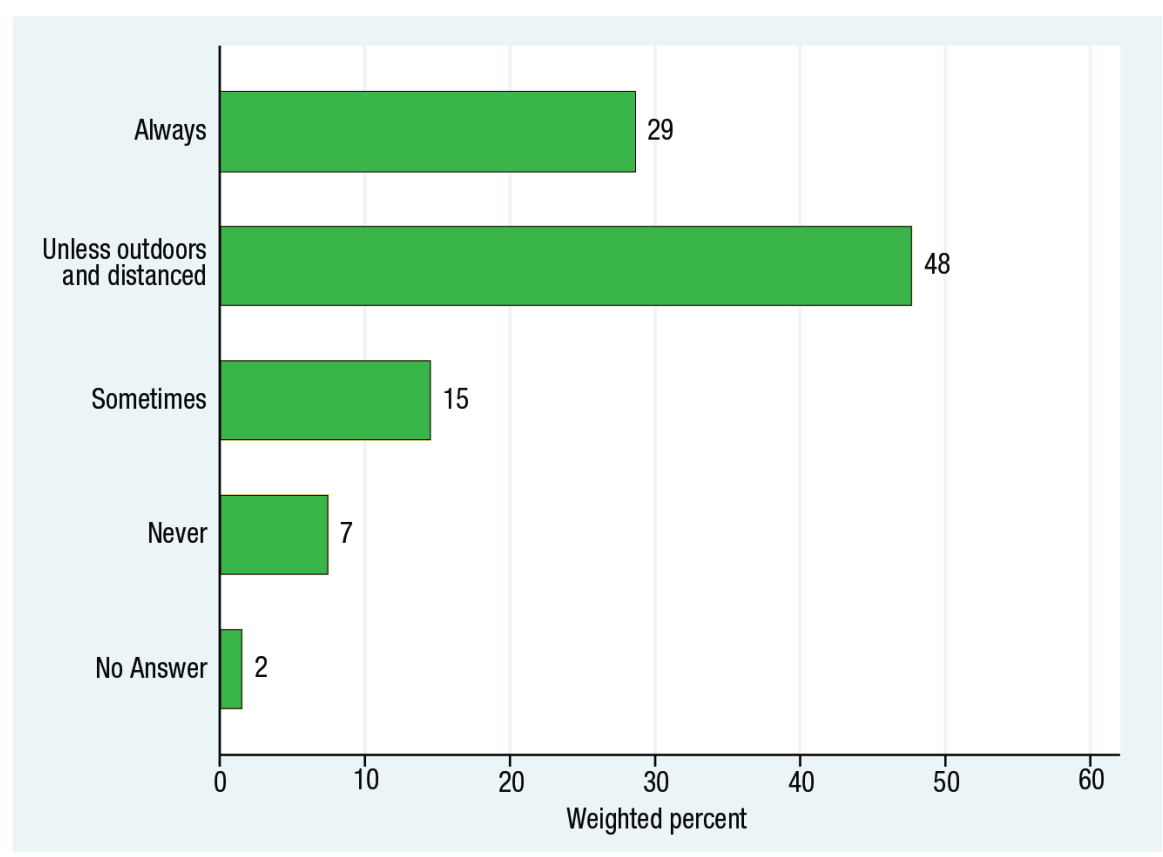

Source: NH Granite State Panel, July $2020(n=959)$. 
Relatively few said they sometimes or never wear a mask. Although at the time of the survey New Hampshire had no statewide mandate for mask wearing, cooperation was not entirely up to individuals, as many businesses and organizations required or requested their use.

Another question asked about personal health concerns (Figure 6):

How worried are you that you, or someone in your family, might become sick with COVID-19 over the next year? Very worried, somewhat worried, slightly worried, or not at all worried?

Most said they were very or somewhat worried that they or family members might become sick. Only 18 percent (disproportionately, conservative media consumers) said they were not at all worried.

Critics of business restrictions and stay-at-home orders have argued that the economic damage from these steps is a greater problem than the disease itself, and the economy should be restarted as soon as possible. The contrary argument from experts has been that opening up the economy before the virus is contained will bring the worst of both worlds: a surge in illness and deaths followed by new economic decline. Our survey posed this policy issue as a question:

Which of the following do you think should be the highest priority of state and federal governments, with regard to COVID-19?

- The government's highest priority should be to contain the spread of COVID-19, even if that hurts the economy.

\section{FIGURE 6. HOW WORRIED ARE YOU THAT YOU, OR SOMEONE IN YOUR FAMILY, MIGHT BECOME SICK WITH COVID-19 OVER THE NEXT YEAR?}

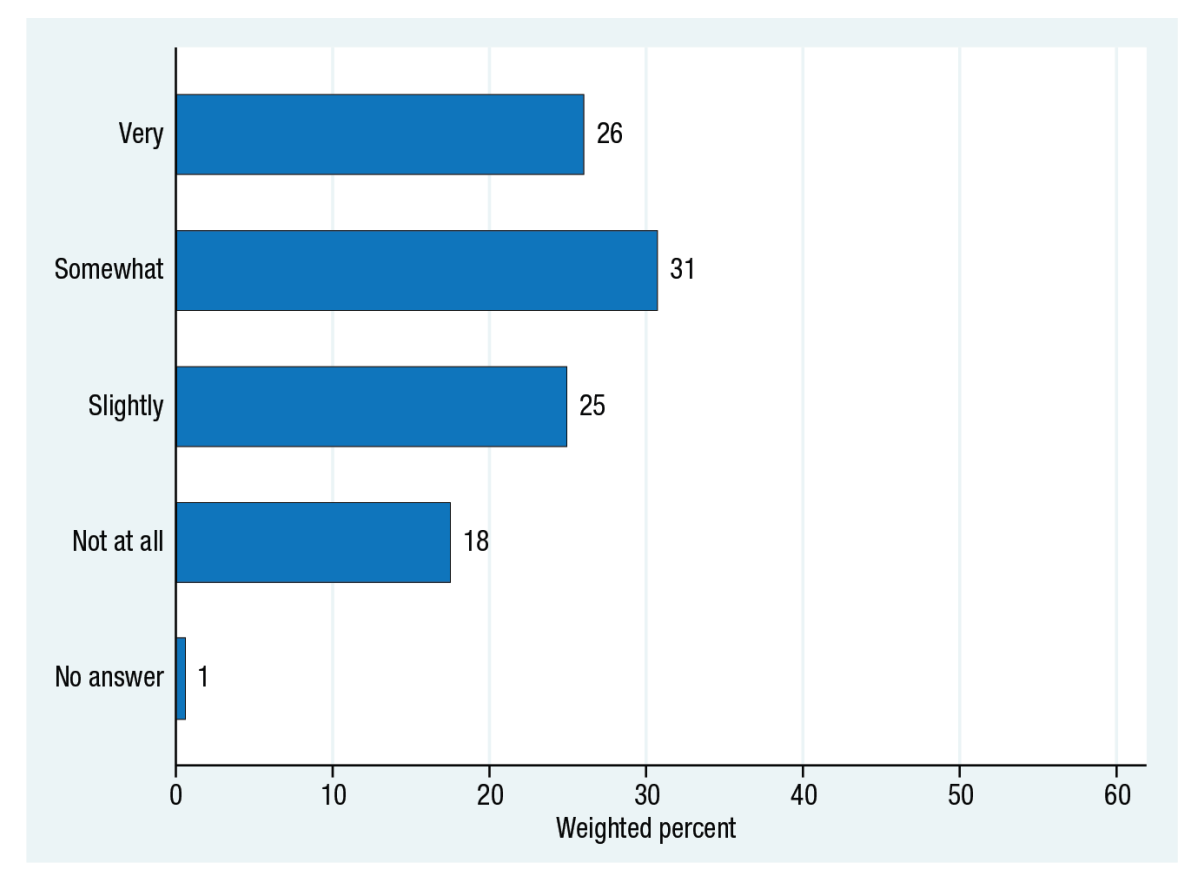

Source: NH Granite State Panel, July $2020(n=959)$.

- The government's highest priority should be to restart the economy, even if that increases the risk to public health.

Some governors made restarting the economy a priority in their states, but early reopening often resulted in new waves of infections. New Hampshire took a slower approach in terms of policy and personal behavior. State residents prioritized containing the spread of the disease by a 2 to 1 margin, as charted in Figure 7.

A fourth question sought people's perspectives on the future:

\section{Which of the following statements} do you think is more accurate concerning the coronavirus or COVID19 in the United States? The worst is yet to come, the worst is behind us, or COVID-19 has not really been a major problem in the United States?
Reflecting warnings from scientific and public health experts that had lately become prominent, survey responses to this question tended toward pessimism (Figure 8). Fiftynine percent thought that the worst is yet to come. Twenty-one percent took the opposite view that the worst is behind us. Which view is realistic should become clear in the months ahead. Only 6 percent denied that COVID-19 was a real problem, but a larger fraction said they did not know or gave no answer.

Taken together, Figures 5-8 depict New Hampshire residents supporting coronavirus precautions in government policies and personal behavior, while concerned about the nation's health as well as their own health and that of their families. These findings reinforce results from earlier surveys in which people were already reporting 


\section{FIGURE 7. SHOULD FEDERAL AND STATE GOVERNMENTS' HIGHEST PRIORITY BE CONTAINING THE SPREAD OF COVID-19, OR RESTARTING THE ECONOMY?}

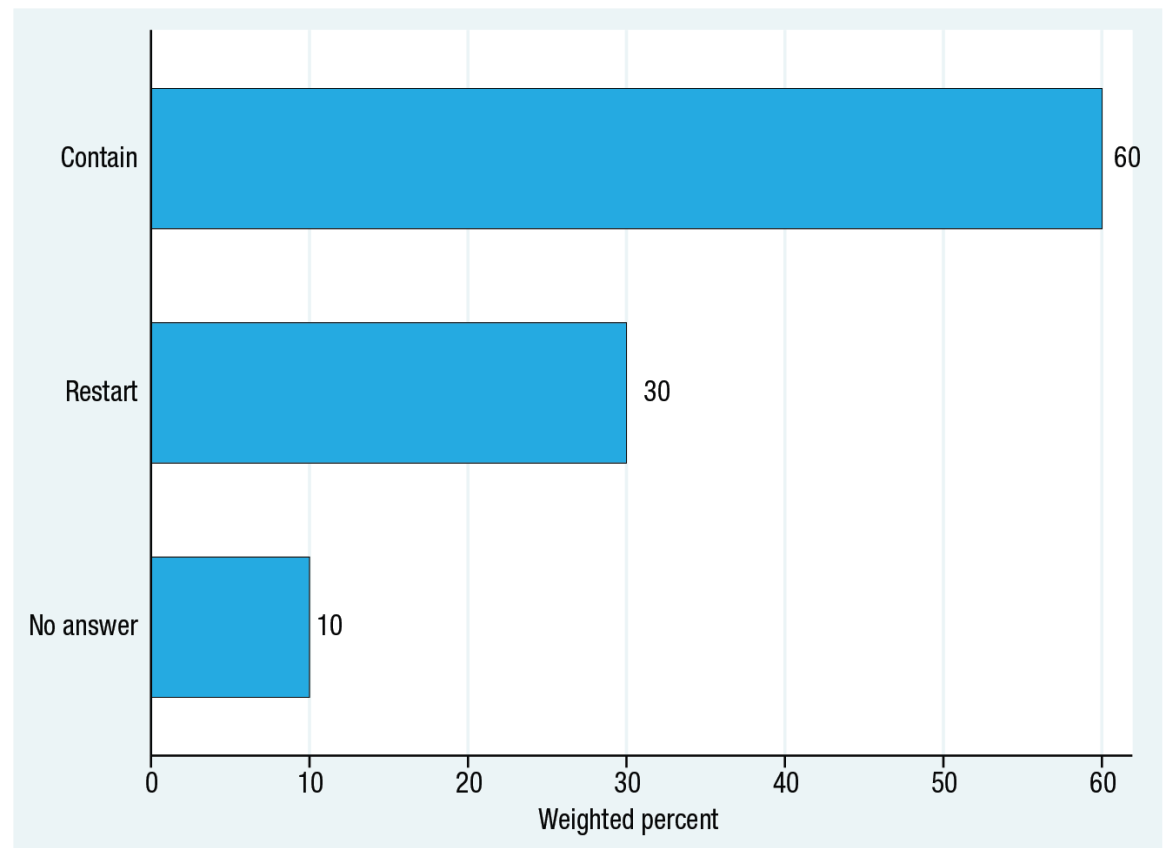

Source: NH Granite State Panel, July $2020(n=959)$.

FIGURE 8. CONCERNING COVID-19 IN THE U.S., IS THE WORST YET TO COME? OR BEHIND US? OR HAS IT NOT REALLY BEEN A MAJOR PROBLEM?

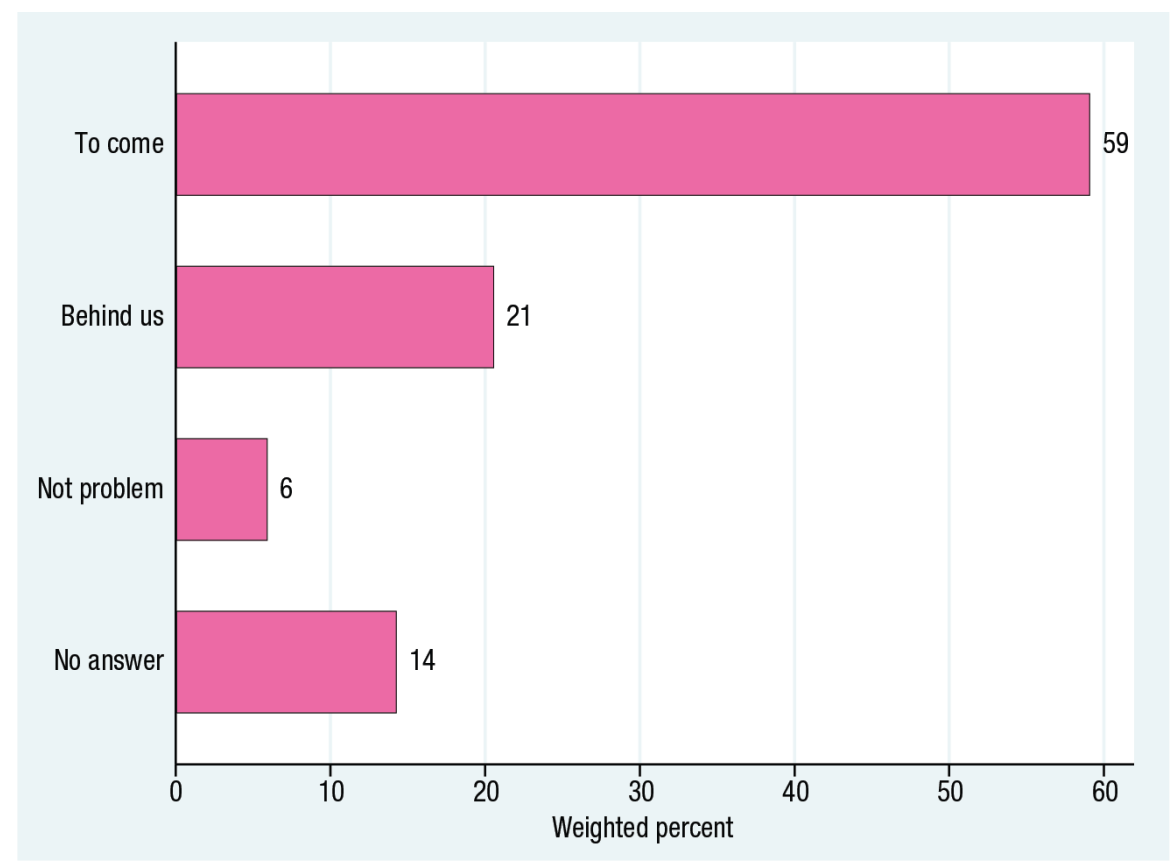

major behavioral change, and said they trust scientists for information but view the federal government with low confidence. ${ }^{9}$ Precautions observed by state residents helped keep per-capita infection rates below those of most other states, although without an effective vaccine the threat has not receded. The scale of this continuing threat has been recognized by scientists and, as these surveys show, by scienceinformed segments of the public. Others, however, view the pandemic through an ideological lens, as seen especially in the wide divisions on general, non-personal questions like prioritizing virus containment versus economic reopening.

\section{Discussion}

Developments in the fall and winter months could be a harsh reality test for conflicting beliefs about the value of mask wearing, personal and family health, and whether or not the worst is behind us. Dr. Robert Redfield, director of the Centers for Disease Control and Prevention (CDC), and himself a Trump appointee, summarized the U.S. dilemma:

For your country right now and for the war that we're in against COVID, I'm asking you to do four simple things. Wear a mask, social distance, wash your hands, and be smart about crowds. You do those four things, it will bring this outbreak down. But if we don't do that, as I said last April, this could be the worst fall from a public health perspective we've ever had. ${ }^{10}$

Source: NH Granite State Panel, July $2020(n=959)$. 
Earlier in this brief, Figures 1 and 2 charted the views of survey respondents who take the pandemic most and least seriously. Majorities reported wearing masks in public, being concerned about their own health and family, placing highest priority on controlling the spread of the virus, and nevertheless expecting that the worst is yet to come. Sizable minorities, however-predominantly conservative media consumers-said they are taking fewer precautions and expressed overall a less serious view. These divergent behaviors and outlooks will influence the course of the pandemic for everyone, in ways that become clear over the months and years ahead.

\section{Endnotes}

1. The Survey Center at the University of New Hampshire conducted this panel survey of 959 New Hampshire residents in July 2020. See Box 1 for a description of the survey.

2. T.G. Safford and L.C. Hamilton, "Views of a Fast-Moving Pandemic: A Survey of Granite Staters' Responses to COVID-19" (Durham, NH: Carsey School of Public Policy, University of New Hampshire, 2020), http://scholars. unh.edu/carsey/396.

3. All of the correlations between COVID-19 responses and news media consumption shown in Figures 1 and 2 are statistically significant $(p<0.001)$, as tested by weighted logit regression.

4. Percentages in Figures 3 to 8 may not add up to 100 , due to rounding.

5. J.L. Bolin and L.C. Hamilton, "The News You Choose: News Media Preferences Amplify Views on Climate Change," Environmental Politics 27, no. 3 (2018): 455-76, DOI: $1080 / 09644016.2018 .1423909$.
6. L.C. Hamilton, J. Hartter, and K. Saito, "Trust in Scientists on Climate Change and Vaccines," Sage Open (2015), https://journals.sagepub.com/ doi/10.1177/2158244015602752.

7. L.C. Hamilton and T.G. Safford, "Ideology Affects Trust in Science Agencies During a Pandemic" (Durham, NH: Carsey School of Public Policy, University of New Hampshire, 2020), http://scholars.unh.edu/carsey/391.

8. W. Saletan, "The Trump Pandemic: A Blow-by-Blow Account of How the President Killed Thousands of Americans," Slate, August 9, 2020, https://slate.com/news-andpolitics/2020/08/trump-coronavirusdeaths-timeline.html.

9. L.C. Hamilton and T.G. Safford, "Trusting Scientists More Than the Government: New Hampshire Perceptions of the Pandemic" (Durham, NH: Carsey School of Public Policy, University of New Hampshire, 2020), http://scholars.unh.edu/carsey/401.

10. J. Whyte, "Coronavirus in Context: CDC Director Discusses Next Steps in the War Against COVID," WebMD interview, 2020, https://www.webmd. com/coronavirus-in-context/video/ robert-redfield.
Box 1. About the Granite State Panel Survey

In July sociologists from the Carsey School of Public Policy at the University of New Hampshire (UNH), working with the UNH Survey Center, added questions to a statewide poll of New Hampshire residents to learn about their perceptions and behavior during the COVID-19 pandemic. This survey employed the Survey Center's Granite State Panel, an online system that surveys panel members recruited randomly from phone numbers across New Hampshire. A total of 959 people responded to the survey from July 16 to July 28 .

The Granite State Panel online survey, like the Granite State Poll telephone survey, routinely calculates weights for mathematical adjustments so that results better represent New Hampshire's adult population in terms of sex, age, education, and region of the state (based on targets from the most recent American Community Survey conducted by the U.S. Census Bureau), as well as political party registration (provided by the New Hampshire Secretary of State). Such weights have been applied to all graphs and analyses in this brief. 


\section{Related Publications From the Carsey School of Public Policy}

"Trusting Scientists More Than the Government: New Hampshire Perceptions of the Pandemic"

(May 2020).

"Views of a Fast-Moving Pandemic: A Survey of Granite Staters' Responses to COVID-19"

(April 2020).

Ideology Affects Trust in Science Agencies During a Pandemic" (March 2020).

"The Zika Virus Threat: How Concerns About Scientists May Undermine Efforts to Combat the Pandemic” (March 2017).

"Conservative and Liberal Views of Science: Does Trust Depend on Topic?" (September 2015).

\section{About the Authors}

Lawrence C. Hamilton is professor of sociology and senior fellow at the Carsey School of Public Policy at the University of New Hampshire.

Thomas G. Safford is associate professor of sociology and faculty fellow at the Carsey School of Public Policy at the University of New Hampshire.

\section{Acknowledgments}

Support for coronavirus questions on the Granite State Panel survey was provided by the Carsey School of Public Policy at the University of New Hampshire.

\section{University of New Hampshire}

Carsey School of Public Policy

The Carsey School of Public Policy at the University of New Hampshire is nationally recognized for its research, policy education, and engagement. The school takes on the pressing issues of the twenty-first century, striving for innovative, responsive, and equitable solutions.

\footnotetext{
Huddleston Hall • 73 Main Street • Durham, NH 03824 (603) 862-2821

TTY USERS: DIAL 7-1-1 OR 1-800-735-2964 (RELAY N.H.) carsey.unh.edu
} 